\title{
Eläinten hyvinvointimerkin tuottojen jakautumisen vaihtoehdot
}

Tapani Yrjölä ${ }^{1}$, Suvi Rinta-Kiikka ${ }^{1}$, Sanni Kiviholma ${ }^{1}$ Jarkko Niemi $^{2}$, Satu Raussi ${ }^{3}$, Tiina Kauppinen $^{3}$, Terhi Latvala ${ }^{3}$, Minna Väre ${ }^{3}$

${ }^{1}$ Pellervon taloustutkimus PTT

${ }^{2}$ Biotalous ja ympäristö, Luonnonvarakeskus, Seinäjoki

${ }^{3}$ Luonnonvarakeskus

\section{TIIVISTELMÄ}

Hankkeessa kartoitettiin kansallisen eläinten hyvinvointimerkin tuottojen jakamisen vaihtoehtoja. Hyvinvointimerkin tuottojen jakamiseksi kehitettiin kahdeksan vaihtoehtoista tulonjakomallia. Kuluttajien näkemyksiä hyvinvointimerkin tulonjakomalleista selvitettiin kyselytutkimuksen avulla. Kuluttajien mielestä merkin tuottojen pitäisi kanavoitua tuottajille. Suosituimpia vaihtoehtoja tulojen jakamiseen olivat kyselyn mukaan malli, jossa kuluttaja maksaa tuotteen hinnassa eläinten hyvinvoinnista ja tuottaja saa merkin tuotot sekä hyvinvointirahasto, josta tuottajalle tilitetään hyvinvointimerkin tuotot. Yleisesti kuluttajat pitivät eläinten hyvinvointimerkkiä tarpeellisena.

\section{Johdanto}

Luonnonvarakeskuksen ja Pellervon taloustutkimus PTT:n hankkeessa on pohdittu kansallisen eläinten hyvinvointimerkin luomista. Eläinten hyvinvointimerkkiin sisältyy runsaasti mahdollisuuksia. Kansallisen, yhtenäisen hyvinvointimerkin etuina yritysten omiin merkkeihin olisi mm. se, että kuluttajille hyvinvointimerkin vaatimukset eläinten olosuhteista, kohtelusta ja hoidosta olisivat yhtenäisiä ja siten helpompia ymmärtää. Yhtenäisen hyvinvointimerkin myötä suomalainen kotieläintuotanto olisi eturintamassa Euroopan mittapuulla ja hyvissä asemissa, jos tulisi aloitteita koko EU:n tasoisesta hyvinvointimerkinnästä ja hyvinvointikriteeristöistä. Yrityksille ja teollisuudelle etua toisi yhteinen panostus merkin kehittämiseen hallinnointiin ja markkinointiin.

Hyvin toteutettuna merkki hyödyttää kaikkia elintarvikeketjun osia. Jokaisen ketjun toimijan oikeudet ja velvollisuudet on määriteltävä selkeästi. Lisäksi tarvitaan taho, joka voi luotettavasti hallinnoida ja valvoa hyvinvointimerkinnän vaatimien toimien toteutumista. Kaikki tämä vaatii kuitenkin yhteistyötä ketjussa sekä voimakasta tahtotilaa edistää eläinten hyvinvointia. Yhtenä tahtotilan edellytyksenä on merkin toimiva hallinnointi ja rahoitus.

Kaikilla ruokaketjun toimijoilla tulee olla kannustimia käyttää hyvinvointimerkintää. Merkkiin liittyvien tuottojen tulisi jakautua ketjussa siten, että ne parantavat eläinten hyvinvointia ja kuluttajien kokemaa hyötyä. Kuluttajille hyvinvointimerkin tuottama lisäarvo syntyy mahdollisuudesta valita eläinten hyvinvointia edistäviä vaihtoehtoja. Kun kuluttajat kokevat saavansa tuotteista ja valinnoistaan lisäarvoa, voisi hyvinvointimerkki tuoda elintarvikeketjuun lisää rahaa. Tuottojen tulisi myös jakautua oikeudenmukaisesti ketjun toimijoiden välillä, ottaen huomioon kilpailu ja kannustimet. 


\section{Materiaalit ja menetelmät}

Eläinten hyvinvointimerkkijärjestelmän tuottojen ja kustannusten jakaminen elintarvikeketjun toimijoiden välillä voidaan toteuttaa monella eri tavalla. Tässä tutkimuksessa koottiin kahdeksan vaihtoehtoista mallia järjestelmän tuottojen jakamiseen ketjun toimijoiden kesken. Osalla malleista on selkeä yhteys jo olemassa oleviin tapoihin kerätä ja jakaa tuottoja joko elintarvikeketjussa tai muulla sektorilla. Osa tulonjakomalleista on enemmän kuvitteellisia avauksia mahdollisuuksista. Mallien kehitystyössä hyödynnettiin muualla toteutettuja vastaavien merkintöjen käytäntöjä.

Seuraavaksi esitetyissä tulonjakomalleissa kuvattiin tuottojen jakautuminen ketjun toimijoiden kesken sekä mietittiin vaihtoehtojen hyötyjä ja heikkouksia.

Kuluttajien mielipiteitä kehitettyjä tulonjakomalleja kohtaan kerättiin kyselytutkimuksella. Kyselyn aineisto kerättiin osana laajempaa tutkimusta, jossa kartoitettiin kuluttajien mielipiteitä eläinten hyvinvointiin liittyvistä asioista. Aineisto kerättiin keväällä 2018. Kyselyaineistoa käsiteltiin suorina jakaumina ja ristiintaulukoinneilla.

\section{Tulokset}

Tuloksissa kuvataan ensin kahdeksan hyvinvointimerkin tulonjakomallia lyhyesti. Sen jälkeen esitellään kuluttajakyselyn tulokset eri malleista.

\section{Kuluttaja maksaa, tuottaja saa}

Kuluttaja maksaa - tuottajaa saa -malli toimii kuten K-ryhmän Tuottajalle kiitos toimintamalli. Hyvinvointimerkityn tuotteen hinta on tavanomaisia tuotteita korkeampi. Lisähinta on merkitty pakkauksiin, esim. 20 senttiä/kg. Kuluttajat tietävät tuotteita ostaessaan, että tuotteiden korkeampi hinta johtuu siitä, että tuotannossa on noudatettu tavanomaista korkeampia eläinten hyvinvointikriteerejä. Kuluttajat tietävät myös, kuinka paljon hyvinvointimerkin tuoma lisähinta on. Lisäksi kuluttajat tietävät, että maksettu lisähinta menee kokonaan tuottajille. Kauppa tilittää lisähinnan tuottajalle.

Mallin vahvuutena on läpinäkyvyys ja tuottojen ohjaaminen suoraan tuottajille. Tuotot voidaan jakaa tasaisesti hyvinvoinnin edistämiseen sitoutuneiden tuottajien kesken. Malli kannustaa kuluttajia valitsemaan vaihtoehdon, jonka tuotot ohjautuvat suoraa eläinten hyvinvoinnin edistämiseen tai ylläpitoon.

Mallin heikkoutena on, että muille ketjun toimijoille syntyy kustannuksia mm. tuotteiden merkitsemisestä, käsittelystä, markkinoinnista ja tuottojen tilityksistä, mutta ei lisätuloja. Vaarana on, ettei teollisuudella ja kaupalla ole kannustimia panostaa hyvinvointimerkittyjen tuotteiden menekinedistämiseen.

\section{Kuluttaja maksaa, koko ketju saa}

Tämä malli poikkeaa edellä esitetystä mallista siinä, että hyvinvointimerkin tuotot kanavoidaan tuottajien lisäksi myös muille ketjun toimijoille. Hyvinvointimerkin tuotot jaetaan kaikkien ketjun toimijoiden kesken. Tuotot voidaan jakaa esimerkiksi tasan kaikkien osapuolten kesken tai laskennallisiin kustannuksiin perustuen.

Mallin etuina on ketjun yhteinen toiminta ja sitoutuminen hyvinvointimerkin markkinointiin, tuottojen jakautuminen tasapuolisesti toimijoiden kesken sekä mahdollisuus kehittää järjestelmää yhdessä. Heikkouksena puolestaan on se, että 
kuluttajan on mahdoton tietää, miten hänen tekemänsä rahallinen panostus ketjussa jakautuu. Lisäksi tulojen jakaminen teettää oman lisätyönsä.

\section{Eläinten hyvinvointirahasto}

Tässä mallissa hyvinvointimerkittyjen tuotteiden kuluttajahinta on korkeampi, kuten malleissa 1 ja 2. Kauppa voi hinnoitella tuotteet haluamallaan tavalla.

Hyvinvointimerkin tuoma lisähinta sisältyy tuotteen hintaan. Kuluttaja tietää tuotetta ostaessaan, mikä osuus hinnasta tilitetään tuottajalle hyvinvointimerkin kautta.

Kauppa tilittää eläinten hyvinvointirahastoon sovitun summan rahaa. Rahastosta korvataan tuottajille ja teollisuudelle merkistä ja hyvinvointitoimenpiteistä aiheutuneita kustannuksia. Tuotot jaetaan tuottajille. Eläinten hyvinvointirahastoa hallinnoi erillinen taho, joka vastaa järjestelmän valvonnasta.

Mallin etuina on hyvinvointimerkin hallinnoinnin ja siihen liittyvien transaktioiden keskittyminen yhdelle taholle sekä mahdollisuus kannustaa tuottajia hyvinvointia parantaviin investointeihin mahdollistamalla investointien osittaisen tukeminen.

Erillinen merkkiä hallinnoiva taho tekee vaihtoehdosta myös jonkin verran edellisiä malleja raskaamman ja nostaa etenkin aloituskustannuksia. Toisaalta pidemmällä aikavälillä tämä malli voi keventää muiden toimijoiden taakkaa. Lisäksi kuluttajien näkökulmasta merkki vaatimuksineen on tässä mallissa puolueettoman tahon hallinnassa.

\section{Vapaaehtoinen hyvinvointilisä}

Hyvinvointimerkityn tuotteen hinta on sama kuin tuotteen, jolla ei ole merkkiä. Tuotteen oston yhteydessä kuluttajalle tarjotaan mahdollisuus maksaa tuotteesta ns. hyvinvointilisää esimerkiksi euron lisähinnalla. Hyvinvointilisä on tuotekohtainen ja kiinteä, esimerkiksi 50 snt/kilo. Kuluttajien maksamat vapaaehtoiset hyvinvointilisät tilitetään kokonaisuudessaan tuottajille. Koska maksu on vapaaehtoinen, kertymä vaihtelee sen mukaan, kuinka paljon kuluttajat haluavat kulloinkin maksaa.

Mallin etuina on sen vapaaehtoisuus kuluttajille sekä mahdollisuus päättää kuinka paljon ja kenelle tuotot merkistä kohdistuvat. Merkin ylläpitäminen ei vaadi kaupalta ja teollisuudelta merkittäviä panostuksia, mutta toisaalta merkin hallinnointi, markkinointi ja kehittäminen jää vähälle panostukselle. Merkin tunnetuksi tekeminen vaatii myös alkuun markkinointia ja kaupan henkilökunnan kouluttamista, joihin kaupalla ei välttämättä ole kannustimia. Myöskään tuottajille merkki ei välttämättä ole houkutteleva, sillä tuotot merkistä ovat epävakaat ja epävarmat. Lisäksi ylimääräinen vaiva maksutilanteessa saattaa tuntua asiakkaista ärsyttävältä.

\section{Korotettu arvonlisävero}

Tässä mallissa hyvinvointimerkittyjen tuotteiden arvonlisäverokanta on korkeampi kuin tavanomaisten tuotteiden. Korkeamman arvonlisäveron tuotot ohjataan tuottajille esimerkiksi Ruokaviraston kautta. Ruokavirasto kerää tilityksiä varten tuotantotietoja tukihakemusten yhteydessä. 
Tämän mallin etuina ovat pieni kuormitus kaupalle ja teollisuudelle. Merkin hallinnointi ja vastuu tuottojen jakamisesta tuottajille on selkeä. Kuluttaja tietää kenelle tuotot menevät ja merkkiä sekä tilityksiä hallinnoi luotettava viranomainen.

Mallin heikkous on se, että kuluttajan on vaikea hahmottaa mikä on tuottajan osuus hinnasta. Viranomaistahon mukana olo saattaa myös heikentää kaupan ja teollisuuden kannustimia merkin edistämiseen. Myös merkin hallinnointikustannukset voivat nousta korkeiksi. Lisäksi tuottajat saisivat tuottojen tilitykset vain kerran vuodessa perustuen edellisenä vuonna kertyneisiin tuottoihin. Vaarana on, että tällöin tuottajia olisi vaikea kannustaa mukaan järjestelmään. Myös hyvinvointimerkin ajatus vapaaehtoisena lisäpanostuksena eläintenhyvinvoinnin edistämiseen saattaisi yhdistyä enemmän viranomaisvaatimuksiin sekä kuluttajien että tuottajien mielissä.

\section{Sijoittajamalli}

Tässä mallissa erillinen taho edistää eläinten hyvinvointia ja koordinoi hyvinvointimerkkiä. Taho hankkii sijoittajilta rahoituksen eläinten hyvinvointimerkin vaatimille investoinneille. Hyvinvointimerkittyjen tuotteiden hinnat määräytyvät markkinoilla. Mikäli markkinoilta saadaan tuottajille maksettavaa korvausta suurempi tuotto, ylimääräinen tuotto palautuu sijoittajille osinkotuottoina.

Mallin etuina on se, että sijoittajaksi voi lähteä kuka tai mikä tahansa. Myös tuottajat voivat lisätä omia tuottomahdollisuuksiaan sijoittamalla yhteisöön. Samoin kauppa ja teollisuus voivat osallistua järjestelmään ja saada siten tuottoa panostuksilleen eläinten hyvinvointiin ja sen edistämiseen. Mallin etuja ovat myös reilu tulonjako tuottajille ja kannustin hyvinvointia lisääviin investointeihin.

Heikkouksina mallissa on sen epävakaus. Jos uusia sijoituksia ei tehdä tulee tuottojen kertyä hyvinvointimerkittyjen tuotteiden myynnin kautta. Lisäksi sijoittamiseen liittyy riski, että tuotot markkinoilta jäävät pienemmiksi, kuin investointikustannukset, jolloin sijoittajat eivät saa tuottoa sijoitukselleen.

Kuluttajien puolestaan on vaikea tietää tuotetta ostaessaan, kenelle hyvinvointimerkin tuotto ohjautuu. Lisäksi kuluttajat voivat kokea epäreiluksi sijoittajien pääsyn tuottoihin.

\section{HV-sovellus}

Tässä tulonjakomallissa hyvinvointimerkityt tuotteet ovat saman hintaisia kuin merkitsemättömät tuotteet. Kuluttajat voivat asentaa puhelimeensa sovelluksen, jonka avulla he voivat maksaa tuottajille vapaaehtoista, haluamansa suuruista tukea eläinten hyvinvoinnin edistämiseen. Tuotteisiin on hyvinvointimerkki ja QR-koodi. Kuluttajat lukevat sovelluksellaan QR-koodin ja voivat lahjoittaa sitä kautta tuottajille rahaa vastineeksi eläinten paremmasta hyvinvoinnista. Applikaation kehittämisestä ja hallinnoinnista vastaa tuottajajärjestö.

Mallin etuina on vapaaehtoisuus kuluttajille, läpinäkyvyys ja mahdollisuus liittää tuotteisiin tila- tai jopa eläinkohtaista tietoa tuotannosta ja olosuhteista. Malli on myös kevyt ja sen yhdistäminen muuhun teknologiaan olisi mahdollista.

Heikkouksina puolestaan on mahdollisuus, että tuotot jäävät epävarmoiksi ja että kuluttajien innostus tukea hyvinvointimerkittyjä tuotteita lopahtaa alkuinnostuksen jälkeen. Myöskään kaikki kuluttajat eivät koe sovelluksen asentamista mielekkäänä tai maksamista sen kautta turvalliseksi. 


\section{Kuukausilahjoitusmalli}

Tämä malli on tuttu hyväntekeväisyydestä. Hyvinvointimerkityt tuotteet ovat lähtökohtaisesti saman hintaisia kuin merkitsemättömät tuotteet. Järjestelmän varat tulevat vapaaehtoisilta kuukausilahjoittajilta. Lahjoittajia voivat olla yksityiset henkilöt, yritykset ja kuka tai mikä tahansa. Lahjoituksen määrä on niin ikään vapaasti määriteltävissä. Lahjoittaja antaa luvan kuukausittain suoritettavalle suoraveloitukselle. Hyvinvointimerkkiä hallinnoi erillinen organisaatio, joka huolehtii varojen keruusta sekä muusta järjestelmän hallinnoinnista. Organisaatio tilittää kertyneet varat tuottajille.

Mallin etuina on sen tuttuus ja yksinkertaisuus: siihen on helppo liittyä ja helppo erota. Heikkouksina on epäsäännöllinen tuottojen kertyminen. Malli vaatii panostusta kuukausilahjoittajien löytämiseksi ja sen lisäksi merkin hallinnointi voi nostaa kustannukset suuriksi suhteessa tuottoihin. Myös tuottajien kannustimet lähteä mukaan järjestelmään ovat vähäiset, sillä tuottojen saaminen on epävarmaa.

\section{Tulokset kuluttajakyselystä}

Kuluttajakyselyyn vastasi 400 vastaajaa. Vastaajien keski-ikä oli 49,7 vuotta. Vastaajien sukupuolijakauma oli tasainen, vastaajista $51 \%$ oli miehiä ja $49 \%$ naisia. Valtaosa vastaajista, $75 \%$, asui kaupungeissa (keskusta ja lähiöt). Taajamissa asui $12 \%$ ja maaseutumaisilla alueilla $14 \%$ vastaajista.

Vastaajista $36 \%$ oli käynyt lukion tai ammattikoulun, $15 \%$ oli suorittanut opistoasteen tutkinnon, $22 \%$ oli suorittanut alemman korkeakoulututkinnon ja $17 \%$ ylemmän korkeakoulututkinnon

Vastaajista $37 \%$ asui yksin, $36 \%$ oli lapsettomia pariskuntia, $18 \%$ vastaajista oli lapsiperheitä. Vastaajista $37 \%$ oli kokopäivätyössä, $34 \%$ eläkkeellä, $9 \%$ työttömiä ja samoin $9 \%$ opiskelijoita. Siten eläkeläiset olivat aineistossa hieman yliedustettuina.

Vastaajat arvioivat tulonjakomalleja viisiportaisella asteikolla: erittäin hyvä ehdotus erittäin huono ehdotus.

Parhaana mallina kuluttajat pitivät vaihtoehtoa, jossa tuotot ohjautuvat suoraan tuottajille. Toiseksi parhaaksi vaihtoehdoksi kuluttajat arvioivat hyvinvointirahaston ja kolmanneksi parhaaksi mallin, jossa tuotot jaetaan ruokaketjun toimijoiden kesken.

Vapaaehtoinen korvaus tuottajalle sai kyselyssä vähiten kannatusta. Myöskään julkisin varoin rahoitetut mallit, hyvinvointituki ja korotettu ALV, eivät saaneet huomattavaa kannatusta. Nämä vaihtoehdot eivät myöskään kokonaisuudessa ole kovin realistisia, eivätkä pohjaa samalla tavalla vapaaehtoisuuteen ja läpinäkyvyyteen kuin parhaiksi arvioidut mallit. 


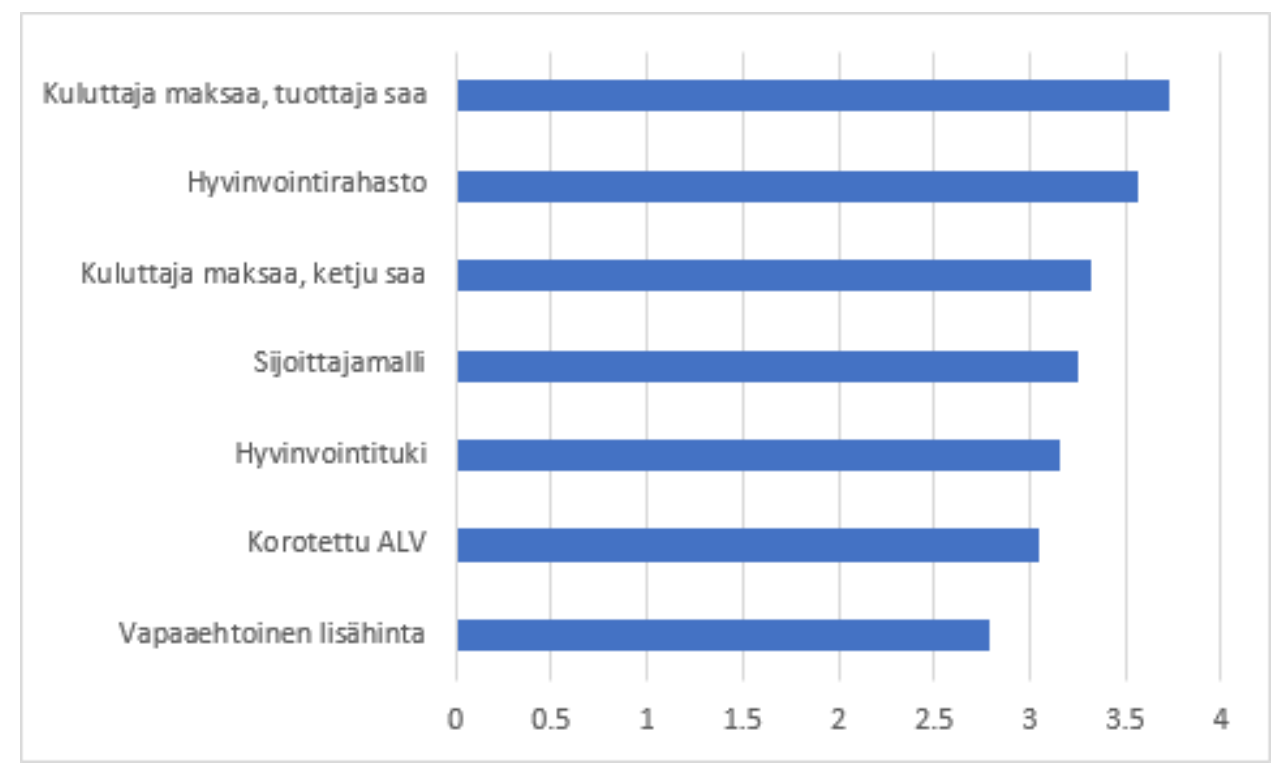

Kuva 1. Tulonjakomallien paremmuusjärjestys kuluttajakyselyn perusteella

Demografisten tekijöiden vaikutus mallien paremmuusjärjestykseen oli vähäinen, joten taustoja on esitetty tässä tiivistelmässä tarkemmin vain kolmen parhaaksi arvioidun tulonjakomallin osalta. Selkeimpiä erottavia taustatekijöitä olivat vastaajien ikä ja asuinalue, mutta esimerkiksi koulutuksen, perhekoon ja tulojen perusteella ei havaittu selkeitä vaihteluita.

Kuluttaja maksaa - tuottaja saa -mallia piti 67 \% vastaajista vähintään melko hyvänä. 3554-vuotiaat pitivät mallia parempana kuin nuorimmat ja vanhimmat vastaajat. Maaseudulla asuvat pitivät mallia hieman parempana kuin kaupungeissa ja taajamissa asuvat.

Hyvinvointirahastoa piti melko hyvänä ehdotuksena $55 \%$ vastaajista, joten voidaan sanoa, että kuluttaja maksaa - tuottaja saa -malli arvioitiin selvästi paremmaksi. Tätä vaihtoehtoa pitivät parhaana 35-54-vuotiaat vastaajat. Kaupunkien reuna-alueilla asuvat vastaajat pitivät ehdotusta huonompana kuin muut.

Kuluttaja maksaa, koko ketju saa -mallin arvioi melko hyväksi 49 \% vastaajista. 3544- sekä yli 65-vuotiaat vastaajat pitävät mallia parempana kuin muut ja 55-64-vuotiaat huonompana kuin muut. Vaihtoehto oli mieluisampi kaupunkien keskustan ja maaseudun asukkaille

Vastaajajoukosta 35-44-vuotiaiden ikäryhmä arvioi lähes kaikki tulonjakoehdotukset ehdotukset paremmiksi kuin muut ikäluokat, lukuun ottamatta vapaaehtoista hyvinvointilisää, hyvinvointitukea ja sijoittajamallia. Nuoret, alle 35-vuotiaat vastaajat taas pitivät vapaaehtoista hyvinvointilisää, hyvinvointitukea ja sijoittaja mallia parempina kuin vanhemmat vastaajat. Vastaajista puolestaan 55-64-vuotiaiden ryhmä piti useammin kaikkia vaihtoehtoja huonompina kuin muut.

Maaseudulla asuvat arvioivat lähes kaikki tulonjakovaihtoehdot hieman paremmiksi kuin taajamissa ja kaupungeissa asuvat vastaajat. Kaupunkien keskustassa asuvat sen sijaan arvioivat vapaaehtoisen hyvinvointilisän, hyvinvointituen ja sijoittajamallin huonommaksi kuin muilla alueilla asuvat.

Sukupuolten välillä ei ollut merkittäviä eroja. Naiset arvioivat julkisista varoista rahoitettavat mallit, korotetun ALV:n ja hyvinvointituen, hieman paremmiksi kuin 
miehet. Naiset myös pitivät tuottaja saa vaihtoehtoa hieman parempana kuin miehet ja miehet puolestaan vaihtoehtoa, jossa tuotot jakautuvat koko ketjun toimijoiden kesken.

\section{Johtopäätökset}

Tuotot eläinten hyvinvointimerkistä voidaan jakaa monella eri tavalla. Paras tapa saattaa olla joku esitettyjen yhdistelmä tai niistä pidemmälle kehitetty vaihtoehto. Tulosten perusteella voidaan kuitenkin yleistää, että kuluttajat kokevat tärkeäksi, että merkin tuotot ohjataan suoraan tuottajalle. Kuluttajat olivat myös varsin yhtä mieltä siitä, että hyvinvointimerkki on tarpeellinen. Tämä kertoo siitä, että merkin kehittämiselle on tarve.

Näkemykset hyvinvointimerkistä olivat varsin yhteneväisiä eri vastaajaryhmien kesken. Keski-ikää lähestyvät vastaajat kokivat merkin hieman muita vastaajia tärkeämmäksi. Vastauksissa olevat erot olivat niin pieniä, että kaikkien kuluttajien tarpeisiin vastaavan merkin kehittämiselle olisi hyvät lähtökohdat.

Vaihtoehtojen vertailussa parhaiksi arvioitiin kuluttaja maksaa, tuottaja saa -malli sekä hyvinvointirahasto. Nämä molemmat vaihtoehdot pohjaavat olemassa oleviin tapoihin hakea tuottoja eläinten paremmasta hyvinvoinnista. Kuluttaja maksaa, tuottaja saa -malli on tuttu K-ryhmän Tuottajalle kiitos -kampanjasta. Hyvinvointirahasto puolestaan on muistuttaa esimerkiksi saksalaista Tierwohl-rahastoa. Muualla käytössä olevat eläinten hyvinvointimerkinnät tarjoavat hyviä esimerkkejä ja kokemuksia kansallisen eläinten hyvinvointimerkin kehittämiseen. 